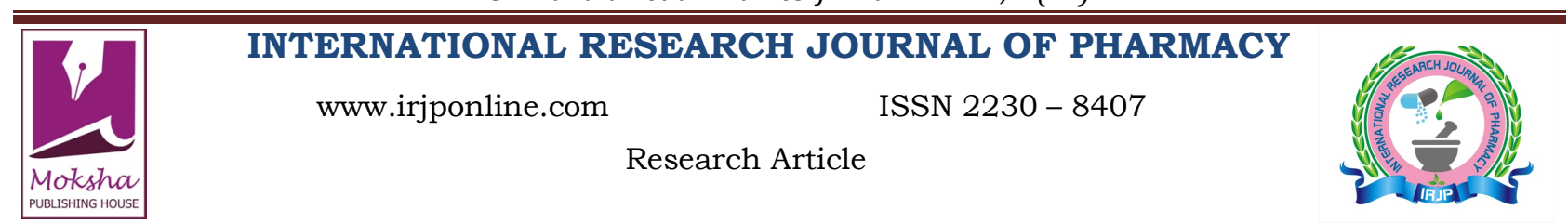

\title{
EVALUATION OF CARDIO PROTECTIVE ACTIVITY OF ETHANOLIC EXTRACT OF ALSTONIA SCHOLARIS ON ISOPROTERENOL INDUCED MYOCARDIAL INFARCTION IN RATS
}

\author{
C.P Pullaiah ${ }^{1}$, M. Venkateswarlu ${ }^{1}$, C. Sridhar ${ }^{1}$, R. Susma $^{1}$, Y. Shivarami Reddy ${ }^{2}$
}

${ }^{1}$ Department of Pharmacology, Sri Padmavathi School of pharmacy, Tirupati, A.P., India

${ }^{2}$ Department of Pharmaceutical chemistry, CES College of pharmacy, Kurnool, A.P., India

*Corresponding Author Email: samuelpharma@gmail.com

Article Received on: 30/09/13 Revised on: 26/10/13 Approved for publication: 10/11/13

DOI: $10.7897 / 2230-8407.041125$

IRJP is an official publication of Moksha Publishing House. Website: www.mokshaph.com

(C) All rights reserved.

\section{ABSTRACT}

The present study was designed to evaluate the cardio protective potential of ethanolic extract of Alstonia scholaris Linn., (Family, Apocynaceae) is an evergreen tree with white, strongly perfumed flowers on isoproterenol-induced Myocardial Infarction (MI) in rats. Five groups of albino rats, each comprising six animals, were selected for this study. Group I served as a normal saline, Group II rats were given isoproterenol (ISO) ( $85 \mathrm{mg} / \mathrm{kg}$ subcutaneously), and Group III rats were treated with propranolol $10 \mathrm{mg} / \mathrm{kg}$ as standard treatment. Groups IV and V rats were given EAS (200 mg/kg and $400 \mathrm{mg} / \mathrm{kg}$, respectively) along with isoproterenol $(85 \mathrm{mg} / \mathrm{kg})$. At end of the study cardiac biomarkers like CK-MB and LDH were estimated to accesses cardio protection. EAS pre treated animals in various doses significantly decreased the levels of CK-MB and LDH when compared with ISO treated animal. It is further conformed by observing the histopathological changes of heart. The study confirms the cardio protective potential of ethanolic extract of Alstonia scholaris against isoproterenol-induced myocardial infarction in rats.

Keywords: Myocardial infarction, cardio protection, cardio biomarkers, isoproterenol.

\section{INTRODUCTION}

Myocardial Infarction (MI) is the leading cause of morbidity and mortality in worldwide and according to the world health organization it will be the major cause of death in the world by the year 2020. ${ }^{1}$ Developing countries like India are struggling to manage the impact of infectious diseases simultaneously with the growing burden on society and health systems caused by non-communicable diseases such as myocardial infarction. In India, myocardial infarction typically occurs 10-15 years earlier than in Western countries. An increasing number of young Indians are succumbing to myocardial infarction. ${ }^{2}$ Myocardial Infarction (MI) results from the prolonged myocardial ischemia with necrosis of myocytes due to interruption of blood supply to an area of heart. ${ }^{3}$ Free radicals and reactive oxygen species have an impact in various disorders like cardiac diseases and cancer which result due to exposure to chemicals and environmental agents, experimental and clinical studies have shown that there is increased generation of reactive oxygen species such as superoxide anion $\left(. \mathrm{O}_{2}^{-}\right)$and hydroxyl radicals $(. \mathrm{OH})$ in heart failure, which involved in the formation of lipid peroxides, damage of cell membrane, and destruction of antioxidative defense system. ${ }^{4}$ Isoproterenol (ISO) induced myocardial necrosis is a well known standard model to study the beneficial effect of many drugs on cardiac dysfunction. ISO is a $\beta$-adrenergic agonist that causes severe stress in myocardium and necrotic lesions in the heart muscles. ISO induced myocardial injury involves membrane permeability alterations, which brings about the loss of functions and integrity of myocardial membranes. The mechanism proposed to explain isoproterenol induced cardiac damage involves generation of highly cytotoxic free radicals through auto-oxidation of catecholamine and has been implicated as one of the causative factor. ${ }^{5}$ It should be appreciated that over the years, while more specific biomarkers of myocardial necrosis became available, the accuracy of detecting myocardial infarction has changed. Such changes occurred when glutamine-oxalic acetic transaminase (GOT) was replaced by lactate dehydrogenase $(\mathrm{LDH})$ and later by creative kinas $(\mathrm{CK})$ and the $\mathrm{MB}$ fraction of $\mathrm{CK}$, i.e. CKMB activity and CKMB mass. Current, more specific and sensitive biomarkers and imaging methods to detect myocardial infarction are further refinements in this evolution ${ }^{6}$. Alstonia scholaris Linn., (Family, Apocynaceae) which is popularly known as the Saptaparna in Sanskrit and Hindi Devil's tree in english. Alstonia scholaris L is an evergreen tree with white, strongly perfumed flowers and a medium to large tree, which grows up to a height of $100 \mathrm{~m}$ height. The plant grows in the Asia Pacific region from India, and Sri Lanka South-East Asia, southern China, Malaysia and the northern part of Australia and Solomon islands. In India it is widely distributed in dried forests like, Western Himalayas, Western Ghats and in the Southern region ${ }^{7,8}$. In various traditions, the decoction prepared from the plant is bitter and used as a tonic, alternative, febrifuge, acrid, thermogenic, digestive, laxative, anthelmintic, astringent, febrifuge, anti-pyretic, depurative, galactogogue, stomachic, cardio tonic and tonic. It is useful in fever, malarial fever, abdominal disorders, diarrhoea, dysentery, dyspepsia, leprosy, skin diseases, pruritus, tumors, chronic and foul ulcers, asthma, bronchitis, cardiopathy, helminthiasis, agalactia and debility. It is given as postnatal conditions to mothers for increasing lactation, and to improve digestion and relieve post-delivery weakness, it is also useful against snake-bite ${ }^{9,10}$. In the literature, there are no clear reports on this plant for cardio protective activity. The present study was attempted to evaluate the cardio protective activity of EAS (Ethanolic extract of Alstonia scholaris) on isoproterenol induced myocardial damage with the reference of heart biochemical markers, antioxidants and histopathology.

\section{MATERIAL AND METHODS \\ Animals}

Experimental animals of either sex weighing 170 to $200 \mathrm{~g}$ were obtained from Raghavendra enterprises, Bangalore, India. The animals were housed in stainless steel cages at a 
controlled room temperature of $24^{\circ} \mathrm{C}$, under a $12 \mathrm{~h}$ light and $12 \mathrm{~h}$ dark cycle. After 1week of acclimatization, the experimental animals were divided randomly in to 5 groups $(n=6)$. The Experiment was carried out as per the guidelines of the Committee for the Purpose of Control and Supervision of Experiments on Animals, New Delhi, India and it is approved by the Institutional Animal Ethics Committee of Creative Educational Society's College Of Pharmacy 1305/AC/09/CPCSCA. Isoproterenol was purchased from Sigma Aldrich USA. Remaining all chemicals was used analytical grade.

\section{Preparation of plant extract}

Plant (Alstonia scholaris) used for experimental purpose was procured from Nallamala forest in Kurnool and was authentified by Dr. B. Sitaram Professor/senior consultant, S.V. Ayurvedic Medical College, Tirupati, India. The dried bark was cleaned and reduced to powdery form with the help of mechanical grinder after which $70 \mathrm{~g}$ of powder sample was exhaustively extracted with $140 \mathrm{ml}$ of ethanol (analytical grade) for 3 days by soxhlet apparatus. The plant material was separated by filtration and the methanolic were concentrated and lyophilized to preserve it. The residue obtained from the extract was stored in a refrigerator at $4^{\circ} \mathrm{C}$ and is air dried and calculates the percentage of yield.

\section{Preliminary Phytochemical Screening}

Ethanolic extract of Alstonia scholaris L. was subjected for the qualitative preliminary phytochemical identifications by the standard methods. Various chemical tests were carried out for the detection of Alkaloids, Carbhohydrates, Glycosides, Saponins, Phytosterols, Tannins, Flavonoids, Proteins and Fixed oils.

\section{Acute toxicity studies}

Acute oral toxicity study was performed as per OECD-423 guidelines. EAS was administered as the dose of $50 \mathrm{mg} / \mathrm{kg}$, $100,500,1000,2000$ and $4000 \mathrm{mg} / \mathrm{kg}$ body weight to groups of animals $(\mathrm{n}=3)$. During the $1 \mathrm{~h}$ of administration rats were observed for gross behavioral changes as described by Irvin scale, and the mortality rate was observed for $72 \mathrm{~h}$ and $\mathrm{LD}_{50}$ value was calculated.

\section{Experimental design}

Isoproterenol was dissolved in normal saline and injected subcutaneously to rats $(85 \mathrm{mg} / \mathrm{kg})$ daily for 2 consecutive days to induce experimental myocardial infarction. ${ }^{4}$ The experimental animals were randomly divided in to 5 groups $(\mathrm{n}=6)$ and treated for duration of 28 days as per the treatment schedule. Group I animals receives normal saline and serve as normal control. Group II animals receive isoproterenol $(85 \mathrm{mg} / \mathrm{kg})$ for last two consecutive days and serve as disease control. Group III animals pretreated with propranolol as standard drug $(10 \mathrm{mg} / \mathrm{kg})$ and the subcutaneous injection with ISO $(85 \mathrm{mg} / \mathrm{kg})$ serve as standard treatment control. Group III animals pretreated with EAS $(20 \mathrm{mg} / \mathrm{kg})$ and the subcutaneous injection with ISO (85 $\mathrm{mg} / \mathrm{kg}$ ) serve as test control at low dose. Group IV animals pretreated with EAS $(400 \mathrm{mg} / \mathrm{kg})$ and the subcutaneous injection with ISO $(85 \mathrm{mg} / \mathrm{kg})$ serve as test control at high dose. At the end of experiment blood was collected and serum separated by centrifugation. Serum was used for various biochemical estimations. Hearts were excised and removed all blood and stored in $10 \%$ formaldehyde solution for histopathological studies.

\section{Biomarkers estimation}

$24 \mathrm{~h}$ after the second injection of ISO, the animals were sacrificed by cervical decapitation, blood was collected and the heart was dissected out. The serum was separated immediately by cold centrifugation and used for determination of cardiac biomarkers markers LDH, CK-MB and total proteins by using commercial diagnostic kits (Agappe Pvt. Ltd, Kerala, India).

\section{Histological examinations}

The hearts were removed, washed immediately with saline and then fixed in $10 \%$ buffered formalin. The hearts stored in $10 \%$ buffered formalin were embedded in paraffin, sections cut at $5 \mu \mathrm{m}$ and stained with hematoxylin and eosin. These sections were then examined under a light microscope for histological changes.

\section{Statistical analysis}

Descriptive statistics such as mean and standard deviation has been calculated for each and every variable for each group. One-way analysis of variance (ANOVA) has been applied for statistical analysis with Turkey as post metric test and a value of $\mathrm{p}<0.001$ has been considered as statistical significance level.

Table 1: Effect of methanolic extra of Alstonia scholaris on serum cardiac manners like CK-MB and LDH and Total protein levels

\begin{tabular}{|c|c|c|c|c|}
\hline Group & Treatment & LDH IU/mg of protein & CK-MB IU/mg of protein & Total Protein g/dl \\
\hline Group-I & Normal Saline & $17.07 \pm 0.8229$ & $166.5 \pm 10.58$ & $9.90 \pm 0.15$ \\
\hline Group-II & Normal Saline + ISO 85 mg/kg & $348.4 \pm 7.901^{\mathrm{a}}$ & $416.9 \pm 16.17^{\mathrm{a}}$ & $4.35 \pm 0.40^{\mathrm{a}}$ \\
\hline Group-III & Propranol $10 \mathrm{mg} / \mathrm{kg}+$ ISO $85 \mathrm{mg} / \mathrm{kg}$ & $61.08 \pm 1.543^{\mathrm{a}}$ & $246.16 \pm 9.16^{\mathrm{a}}$ & $8.10 \pm 0.12^{\mathrm{a}}$ \\
& & & & \\
\hline Group-IV & EAS 200 mg/kg + ISO $85 \mathrm{mg} / \mathrm{kg}$ & $153.1 \pm 3.242^{\mathrm{a}}$ & $316.19 \pm 2.60^{\mathrm{a}}$ & $5.60 \pm 0.23^{\mathrm{b}}$ \\
\hline Group-V & EAS $400 \mathrm{mg} / \mathrm{kg}+$ ISO $85 \mathrm{mg} / \mathrm{kg}$ & $136.8 \pm 1.996^{\mathrm{a}}$ & $286.64 \pm 3.16^{\mathrm{a}}$ & $7.43 \pm 0.17^{\mathrm{a}}$ \\
\hline
\end{tabular}

${ }^{\mathrm{a}}$ Indicates $\mathrm{P} \leq 0.001$ when compared with ISO control; ${ }^{\mathrm{b}}$ Indicates $\mathrm{P} \leq 0.05$ when compared with ISO control

\section{RESULTS}

In the acute toxicity study none of the dose of EAS was shown mortality even at $4000 \mathrm{mg} / \mathrm{kg}$. Therefore, $1 / 10^{\text {th }}$ and $1 / 20^{\text {th }}$ of the dose were selected for the study as low and high test doses. There was a significant elevation in cardiac markers like $\mathrm{LDH}$ and $\mathrm{CK}-\mathrm{MB}$ profiles in isoproterenol treated animals when it compared to the controls (Table 1). In the animals pretreated with EAS in IV and $\mathrm{V}$ groups a significant reduction $(\mathrm{p}<0.001)$ in the cardiac markers like LDH and CK-MB level was observed when compared with the isoproterenol treated rats (Group II). The decrement of cardiac markers is almost similar to the standard treatment with propranolol $10 \mathrm{mg} / \mathrm{kg}$ i.e. Group II animals. The total protein levels were significantly $(\mathrm{P} \leq 0.001)$ decreased in 
control group (GII) when compared with normal animals. The total protein levels were significantly increased standard groups (GIII) animals when compared with control animals. In the same manner the test groups i.e., Group IV and Group $\mathrm{V}$ which were pretreated with EAS in various doses such as $200 \mathrm{mg} / \mathrm{kg}$ and $400 \mathrm{mg} / \mathrm{kg}$ of bodyweight, were shown a significant increase in total protein levels in the dose dependent manner, when it was compared with control group (GII). Histopathological examination of myocardial tissue of normal animals shows a clear integrity of myocardial cell membrane. Endocardium and pericardium were seen within the normal limits. No inflammatory cells infiltration was observed in normal rat heart. In isoproterenol treated animals shows that a focal myonecrosis with myophagocytosis and lymphocytic infiltration (myocarditis) was observed. The animals were pre-treated with EAS at 200 and $400 \mathrm{mg} / \mathrm{kg}$ doses were found less damaged and low fatty infiltration was observed when compared with ischemic control group.
NORMAL

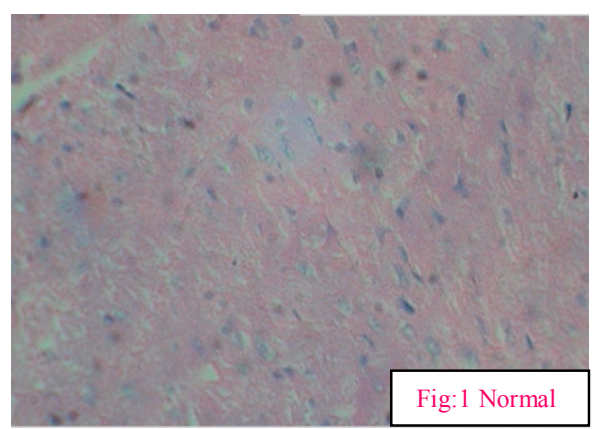

ISOPROTERENOL $85 \mathrm{mg} / \mathrm{kg}$

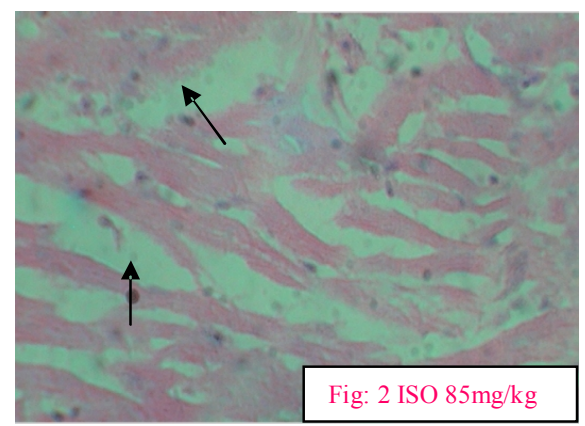

\section{PROPRANOLOL $10 \mathrm{mg} / \mathrm{kg}$}

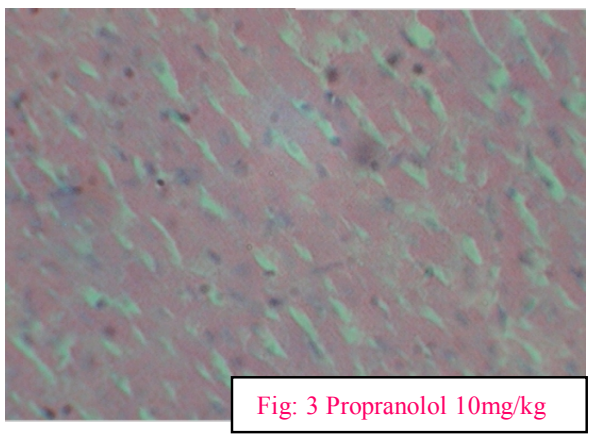

\section{EAS 200mg/kg +ISO 85mg/kg}

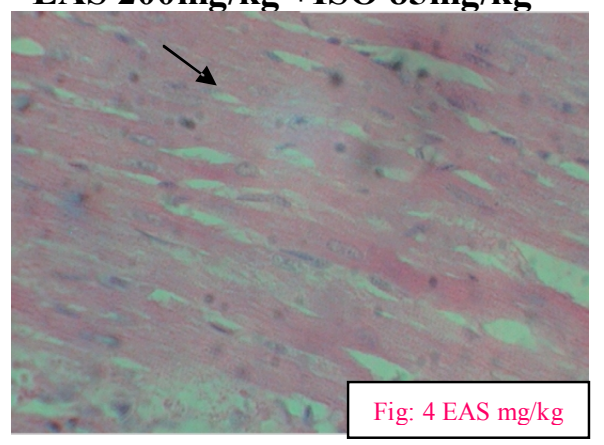

EAS 400mg/kg+ ISO 85mg/kg

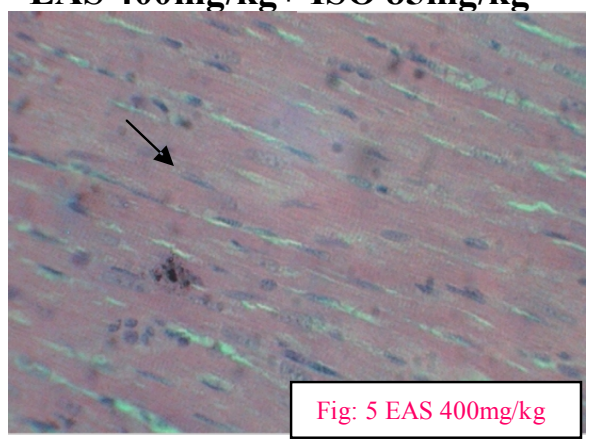

Figure 1: Effect of ethanolic extract of Alstonia scholaris L (EAS) on histopathological changes in rat myocardial tissue. Normal showing normal myocardium showing normal myocardium. Isoproterenol $85 \mathrm{mg} / \mathrm{kg}$ showing focal myonecrosis with cell infiltration. Propranolol $10 \mathrm{mg} / \mathrm{kg}$ showing decreased degree of necrosis and less infiltration of inflammatory cells. EAS $200 \mathrm{mg} / \mathrm{kg}+$ ISO $85 \mathrm{mg} / \mathrm{kg} \mathrm{showing} \mathrm{reduced} \mathrm{focal} \mathrm{interstitial}$ inflammatory response and EAS $400 \mathrm{mg} / \mathrm{kg}+$ ISO $85 \mathrm{mg} / \mathrm{kg}$ showing reduced fragmentation of myocardial fibers and focal interstitial inflammatory response. 


\section{DISCUSSION}

The present was aimed to evaluate the cardio protective activity of ethanolic extract of Alstonia scholaris on Isoproterenol induced myocardial infarction in albino rats. Isoproterenol is well known cardio toxic agent due to its ability to destruct myocardial cells. As a consequence, cytosolic enzymes such as LDH, ALT, AST and CPK were released into blood stream and serve as the diagnostic markers of myocardial tissue damage ${ }^{11}$. The amount of these cellular enzymes present in blood reflects the alterations in plasma membrane integrity and or permeability. It is well known that isoproterenol-induced myocardial injury is mediated primarily via the $\beta_{1}$-adrenergic receptor. Acute $\beta_{1}$ adrenergic receptor stimulation not only rapidly generates reactive oxygen species, but also depresses total cellular antioxidant capacity, down regulates copper-zinc superoxide dismutase enzyme activity, protein and mRNA and reduces glutathione level, leading to the loss of membrane integrity and inducing heart contractile dysfunction and myocytes toxicity finally producing myocardial necrosis ${ }^{12}$. Number of studies strongly suggests that free radicals play an important role in catecholamine-induced cardio toxicity by causing peroxidation of membrane phospholipids, which can result in permeability changes in the membrane as well as intracellular calcium overload $^{13}$. In our study, isoproterenol treated rats showed significant elevation in the levels of these diagnostic marker enzymes. Moreover, elevated levels of these enzymes are an indicator of the severity of isoproterenol-induced myocardial membrane necrosis. The preliminary phytochemical screening showed that ethanolic extract of Alstonia scholaris presence of high level of secondary metabolites like flavonoids, phenolic compounds and phytosterols. Number of investigations suggested that the like flavonoids, phenolic compounds have shown an important in reduction of oxygen free radicals. Alteration in LDH and CK$\mathrm{MB}$ has been considered as one of the most important cardiac marker of myocardial infarction. Wexler and Kittinger et al. demonstrated that there was a dramatic rise and fall in serum $\mathrm{CK}-\mathrm{MB}$ and $\mathrm{LDH}$ following isoproterenol induced $\mathrm{MI}$ in rats, and the degree of rise and fall in serum enzyme activities were commensurate with the extent of the myocardium infarcted $^{14}$. In the present study, ISO treated rats showed significant elevation in the levels of these diagnostic marker enzymes (LDH and CK-MB). Moreover, elevated levels of these enzymes are an indicator of the severity of ISO-induced myocardial membrane necrosis, which is in line with an earlier report ${ }^{15}$. The prior administration of EAS (200 and $\left.400 \mathrm{mg} \mathrm{kg}^{-1}\right)$ showed significant $(\mathrm{p}<0.001)$ reduction in ISO induced elevated serum marker enzymes. This reduction in enzyme levels could be due to its action on maintaining membrane integrity thereby restricting the leakage of these enzymes. The presence of alkaloids, steroids, flavonoids and triterpenoids is supposed to be responsible for the various pharmacological effects of Alstonia scholaris. ${ }^{15}$ Since, flavonoids are one of the most popular compounds in the plant kingdom and have effectiveness in reducing blood lipid, as an anti-oxidative, in assimilating cholesterol, inhibiting thrombosis, dilating the coronary artery, etc. ${ }^{15}$ Ramachandra et al, suggested that the methanolic extract of Alstonia scholaris possess antioxidant activity, which might be helpful in preventing of various Oxidative stress- related diseases and also the present work provides the evidence for presence of bioactive compounds like flavonoids and phenols ${ }^{16}$. The present study revealed that there will be significant decrease cardiac markers like LDH and CK-MB which are a prominent diagnostic agent in MI. The cardiac protective effect of EAS is attributed due to the presence of various phyto constituents like flavonoids polyphenols and phytosterols which are proven antioxidant. During tissue damage the protein levels were decreased. In the present study a significant decreased in total protein level in control when compared with normal. In the same manner the total protein levels were significantly increased in EAS treated groups in dose dependent manner. Histopathological studies reveal that there was more myocardial damage and focal myonecrosis and chronic infiltration of inflammatory cells found in the animals treated with isoproterenol $85 \mathrm{mg} / \mathrm{kg}$ when compared with normal group. The animals were pretreated with Propranolol $10 \mathrm{mg} / \mathrm{kg}$ and EAS at low and high doses were found less damage and low fatty infiltration when it was compared with control group. This confirming furthers the cardio protective activity of methanolic extract of Alstonia scholaris in the present study. The present data indicate that EAS may provide potential therapeutic value in the treatment of myocardial infarction. The beneficial effects of Alstonia scholaris can be reproduced in human beings, these findings may represent a novel prophylactic therapy for MI.

\section{CONCLUSION}

This study thus demonstrates the cardio protective effect of EAS (200 and $400 \mathrm{mg} / \mathrm{kg}$, p.o.). This extract was found to be most effective in the reduction of biomarkers of the heart and restoration of biochemical and histopathological alterations. Further isolation, characterization and purification of the active constituents and further experimentation would be necessary to elucidate the exact mechanism of action of Alstonia scholaris L.

\section{REFERENCES}

1. Lopez AD and CC Murrau. The global burden disease, 1990-2020. Nat. Med 1998; 4: 1241-1243. http://dx.doi.org/10.1038/3218 PMid:9809543

2. Whelan DJ. Heart failure disease management: Implementation and outcomes. Cardiol. Rev 2005; 13(5): 231-239. http://dx.doi.org/10.1097 /01.crd.0000135765.60824.2f

3. Krishnaswami S. Observations on serial changes in coronary artery disease in Indians. Curr Sci 1998; 74(12): 1064-1068.

4. Rajadurai M, Stanely Mainzen Prince P. Preventive effect of naringin on cardiac markers, electrocardiographic patterns and lysosomal hydrolases in normal and isoproterenol-induced myocardial infarction in Wister rats. Toxicology 2007; 230(2-3): 178-88. http://dx.doi.org/10.1016 /j.tox.2006.11.053 PMid:17188415

5. Grimm D, Elsner D and Schunkert H. Development of heart failure fallowing isoproterenol administration in rats: role of rennin angiotensin system. Cardiovas Res 1998; 37: 91-100. http://dx.doi.org/10.1016/ 0008-6363(97)00212-5

6. PO Collinson, PJ Stubbs, AC Kessler. Multicenter evaluation of the diagnostic value of cardiac troponin T, CK-MB mass and myoglobin for assessing patients with suspected acute coronary syndrome in routine clinical practice. Heart 2003; 89: 280-286. http://dx.doi.org/10.1136/ heart.89.3.280 PMid:12591831 PMCid:PMC1767587

7. Arulmozhi S, Mitra Mazumder P, Ashok P, Sathya Narayanan L. Pharmacological activities of Alstonia scholaris Linn. (Apocynaceae)a review. Pharmacog Rev 2007; 1(1): 163-170.

8. Satyavati GV, Gupta AK, Tandon N. Medicinal plants of India. New Delhi, India: Indian Council of Medical Research; 1987. p. 230-239.

9. Nadkarni AK. Ed. Indian Materia Medica, $3^{\text {rd }}$ ed. Mumbai, India: Popular Press Ltd; 1976. p. 1308-1315.

10. Sharma P. Dravyaguna Vigyan. Varanasi, India: Chaukhambha Bharti Academy; 2008.

11. Adams JE, Abendschein DR, Jaffee AS. Biochemical markers of myocardial injury: is MB creatine kinase the choice for the 1990s? Circulation 1993; 88: 750-763. http://dx.doi.org/10.1161 /01.CIR.88.2.750 PMid:8339435

12. Wexler BC, Judd JT, Kittinger GW. Myocardial necrosis induced by isoproterenol in rats. Angelology 1979; 30(6): 377-394. http://dx. doi.org/10.1177/000331977903000602 
13. Sharma Meenu, Kishore Kamal, Gupta Suresh K, Joshi Sujata and Arya Dharamvir S. Cardioprotective potential of Ocimum sanctum in isoproterenol induced myocardial infarction in rats. Molecular and Cellular Biochemistry 2001; 225: 75-83. http://dx.doi.org/10.1023/ A: 1012220908636

14. Dwinter RJ, Koster RW, Sturk A, Sanders GT. Value of myoglobin, Troponin $\mathrm{T}$ and CK-MB mass in ruling out an acute myocardial infarction in the emergency room. Circulation 1995; 92: 3401-3407. http://dx.doi.org/10.1161/01.CIR.92.12.3401

15. Baliga Manjeshwar Shrinath. Review of the Phytochemical, Pharmacological and Toxicological Properties of Alstonia Scholaris Linn. R. Br (Saptaparna) Chin J Integr Med; 2011. p. 1-41.
16. Ramachandra, Shajyothi C and Rai S Padmalatha. Antioxidant activity of Alstonia scholarsis extracts containing flavonoids and phenolic compounds 2012; 4(3): 424-426.

\section{Cite this article as:}

C.P Pullaiah, M. Venkateswarlu, C. Sridhar, R. Susma, Y. Shivarami Reddy. Evaluation of cardio protective activity of ethanolic extract of Alstonia scholaris on isoproterenol induced myocardial infarction in rats. Int. Res. J. Pharm. 2013; 4(11):112-116 http://dx.doi.org/10.7897/2230-8407.041125 